\title{
Front Matter: Volume 7032
}

, "Front Matter: Volume 7032," Proc. SPIE 7032, Plasmonics: Metallic Nanostructures and Their Optical Properties VI, 703201 (29 September 2008); doi: 10.1117/12.806020

SPIE Event: NanoScience + Engineering, 2008, San Diego, California, United SPIE. States 


\section{PROCEEDINGS OF SPIE}

\section{Plasmonics: Metallic Nanostructures and Their Optical Properties VI}

Mark I. Stockman

Editor

10-14 August 2008

San Diego, California, USA

Sponsored and Published by

SPIE

Volume 7032 
The papers included in this volume were part of the technical conference cited on the cover and title page. Papers were selected and subject to review by the editors and conference program committee. Some conference presentations may not be available for publication. The papers published in these proceedings reflect the work and thoughts of the authors and are published herein as submitted. The publisher is not responsible for the validity of the information or for any outcomes resulting from reliance thereon.

Please use the following format to cite material from this book:

Author(s), "Title of Paper," in Plasmonics: Metallic Nanostructures and Their Optical Properties VI, edited by Mark I. Stockman, Proceedings of SPIE Vol. 7032 (SPIE, Bellingham, WA, 2008) Article CID Number.

ISSN 0277-786X

ISBN 9780819472526

Published by

SPIE

P.O. Box 10, Bellingham, Washington 98227-0010 USA

Telephone +1 3606763290 (Pacific Time) · Fax +1 3606471445

SPIE.org

Copyright (c) 2008, Society of Photo-Optical Instrumentation Engineers

Copying of material in this book for internal or personal use, or for the internal or personal use of specific clients, beyond the fair use provisions granted by the U.S. Copyright Law is authorized by SPIE subject to payment of copying fees. The Transactional Reporting Service base fee for this volume is $\$ 18.00$ per article (or portion thereof), which should be paid directly to the Copyright Clearance Center (CCC), 222 Rosewood Drive, Danvers, MA 01923. Payment may also be made electronically through CCC Online at copyright.com. Other copying for republication, resale, advertising or promotion, or any form of systematic or multiple reproduction of any material in this book is prohibited except with permission in writing from the publisher. The CCC fee code is 0277-786X/08/\$18.00.

Printed in the United States of America.

Publication of record for individual papers is online in the SPIE Digital Library.

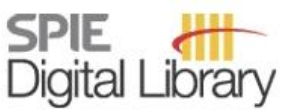

SPIEDigitalLibrary.org

Paper Numbering: Proceedings of SPIE follow an e-First publication model, with papers published first online and then in print and on CD-ROM. Papers are published as they are submitted and meet publication criteria. A unique, consistent, permanent citation identifier (CID) number is assigned to each article at the time of the first publication. Utilization of CIDs allows articles to be fully citable as soon they are published online, and connects the same identifier to all online, print, and electronic versions of the publication. SPIE uses a six-digit CID article numbering system in which:

- The first four digits correspond to the SPIE volume number.

- The last two digits indicate publication order within the volume using a Base 36 numbering system employing both numerals and letters. These two-number sets start with 00, 01, 02, 03, 04, 05, $06,07,08,09,0 \mathrm{~A}, 0 \mathrm{~B} \ldots \mathrm{OZ}$, followed by 10-1Z, 20-2Z, etc.

The CID number appears on each page of the manuscript. The complete citation is used on the first page, and an abbreviated version on subsequent pages. Numbers in the index correspond to the last two digits of the six-digit CID number. 


\section{Contents}

ix Conference Committee

xiii Revivals of molecular nonlinear optics in physics, chemistry, and life sciences (Plenary Paper) [7040-100]

J. Zyss, Lab. de Photonique Quantique et Moléculaire, CNRS, Institut d'Alembert (France)

\section{PLASMONIC NANOANTENNAS I}

$703206 \quad$ Nanoantennas with short-wavelength resonance [7032-05]

R. Osgood III, G. Walsh, D. Ziegler, J. Carlson, L. Belton, B. Kimball, U.S. Army Natick Soldier Research Development and Engineering Ctr. (United States)

703207 Tuning the optical properties by engineering the topologic shape of Ag nanorods [7032-06] Z.-Y. Zhang, Y.-P. Zhao, Univ. of Georgia (United States)

\section{PLASMONIC NANOANTENNAS II}

7032 OB Nano-structured metallic electrodes for plasmonic optimized light-emitting diodes [7032-10]

U. Geyer, J. Hetterich, C. Diez, D. Z. Hu, D. M. Schaadt, U. Lemmer, Univ. Karlsruhe (Germany)

ULTRAFAST NANOPLASMONICS

7032 OE Femtosecond coherent control of surface plasmon propagating direction [7032-13] S. B. Choi, D. J. Park, Y. K. Jung, Seoul National Univ. (Korea, Republic of); J. H. Kang, Q.-H. Park, Korea Univ. (Korea, Republic of); C. C. Byeon, M. S. Jeong, Advanced Photonics Research Institute (Korea, Republic of); D. S. Kim, Seoul National Univ. (Korea, Republic of)

\section{QUANTUM NANOPLASMONICS AND RELATED PHENOMENA I}

7032 0J Nanoplasmonic renormalization and enhancement of Coulomb interactions [7032-18] M. Durach, A. Rusina, Georgia State Univ. (United States); V. I. Klimov, Los Alamos National Lab. (United States); M. I. Stockman, Georgia State Univ. (United States)

\section{QUANTUM NANOPLASMONICS AND RELATED PHENOMENA II}

7032 ON Quantum optics and atomic physics using plasmonics (Invited Paper) [7032-22]

D. E. Chang, M. D. Lukin, Harvard Univ. (United States) 
7032 OR Enhanced performance of high-power GaN LED by mediating surface plasmon polaritons [7032-27]

K. Choi, J. Yoon, S. H. Song, Hanyang Univ. (Korea, Republic of); H. Kim, J.-H. Kim, Samsung Electro-Mechanics Co., Ltd. (Korea, Republic of)

\section{NANOPLASMONIC SENSING, INCLUDING SERS}

7032 OT Novel plasmonic nanodevices for few/single molecule detection (Invited Paper) [7032-92] F. De Angelis, G. Das, Univ. of Magna Graecia (Italy) and CalMED s.r.l. (Italy); M. Patrini, A. Volta Univ. of Pavia (Italy); P. Candeloro, Univ. of Magna Graecia (Italy); C. Liberale, Univ. of Magna Graecia (Italy) and CaIMED s.r.l. (Italy); G. Cojoc, Univ. of Magna Graecia (Italy); F. Mecarini, Univ. of Magna Graecia (Italy) and CalMED s.r.l. (Italy); E. Di Fabrizio, Univ. of Magna Graecia (Italy), CalMED s.r.I. (Italy), and TASC National Lab., CNR-INFM (Italy)

7032 OU Distance and molecular weight dependence of surface enhanced fluorescence in conjugated polymer thin films [7032-30]

M. S. Griffo, S. A. Carter, Univ. of California, Santa Cruz (United States)

7032 OV Tunable multilayered nanospheres as probes for surface-enhanced Raman spectroscopy [7032-31]

A. K. Kodali, R. Bhargava, Univ. of Illinois at Urbana-Champaign (United States)

7032 OW Fabrication of biosensor arrays via DPN and detection by surface enhanced resonance Raman scattering [7032-33]

R. J. Stokes, J. A. Dougan, E. Irvine, Univ. of Strathclyde (United Kingdom); J. Haaheim, P. Stiles, T. Levesque, Nanolnk, Inc. (United States); D. Graham, Univ. of Strathclyde (United Kingdom)

\section{OPTICAL FUNCTIONALITIES IN PLASMONICS AND RELATED SUBJECTS}

$70320 Z \quad$ Nanoparticle aggregation and relaxation effects in ferrofluids: studied through anisotropic light scattering [7032-36]

C. Rablau, P. Vaishnava, Kettering Univ. (United States); C. Sudakar, R. Tackett, G. Lawes, R. Naik, Wayne State Univ. (United States)

\section{TRANSFER AND CONCENTRATION OF OPTICAL ENERGY ON NANOSCALE I}

703212 Ultrasmall plasmonic nanocavities: using slow waves, slow light, and localized fields (Invited Paper) [7032-39]

M. Orenstein, E. Feigenbaum, Technion - Israel Institute of Technology (Israel)

\section{TRANSFER AND CONCENTRATION OF OPTICAL ENERGY ON NANOSCALE II}

703215 Unidirectional signal transfer in quantum-dot systems via optical near-field interactions (Invited Paper) [7032-43]

W. Nomura, T. Yatsui, T. Kawazoe, M. Naruse, N. Tate, M. Ohtsu, The Univ. of Tokyo (Japan) 
703216 Properties of three-dimensional plasmonic slot waveguides [7032-44]

G. Veronis, Louisiana State Univ. (United States); S. Fan, Stanford Univ. (United States)

PLASMONIC PROPERTIES OF COMPLEX NANOSTRUCTURES

7032 1A Electromagnetic eigenstates of finite cylinders and cylinder-clusters: application to macroscopic response of meta-materials (Invited Paper) [7032-48]

D. J. Bergman, Tel Aviv Univ. (Israel)

7032 IE Measuring the differential scattering cross-section of gold nanoparticles [7032-52]

C. Huang, A. Bouhelier, G. Colas des Francs, J.-C. Weeber, A. Dereux, Institut Carnot de Bourgogne, CNRS, UMR 5209, Univ. de Bourgogne (France)

SPECIAL SESSION: NONLINEAR AND ULTRAFAST NANOPLASMONICS

7032 i Role of local fields and defects in the nonlinear response of metal nanostructures (Invited Paper) [7032-57]

M. Kauranen, H. Husu, S. Kujala, B. K. Canfield, Tampere Univ. of Technology (Finland);

J. Laukkanen, B. Bai, M. Kuittinen, J. Turunen, Univ. of Joensuu (Finland); J. Kontio,

J. Viheriälä, T. Niemi, Tampere Univ. of Technology (Finland); E. Chandler, J. A. Squier,

Colorado School of Mines (United States)

\section{SPECIAL SESSION: NOVEL TRENDS IN NANOPLASMONICS II}

7032 IP Near-field studies of surface plasmon generation: optical and terahertz studies (Invited Paper) [7032-63]

H. W. Kihm, K. G. Lee, M. A. Seo, K. J. Ahn, Seoul National Univ. (Korea, Republic of);

A. J. L. Adam, Delft Univ. of Technology (Netherlands); J. H. Kang, Q. H. Park, Korea Univ. (Korea, Republic of); P. C. M. Planken, Delft Univ. of Technology (Netherlands); D. S. Kim, Seoul National Univ. (Korea, Republic of)

\section{PLASMONIC SENSING AND ENHANCEMENT}

7032 1Q Nanophotonics bio-sensor using gold nanostructure (Invited Paper) [7032-64]

M. Naya, T. Tani, Y. Tomaru, J. Li, N. Murakami, FUJIFILM Corp. (Japan)

7032 is Surface-plasmon fields in two-dimensional arrays of gold nanodisks [7032-66] W. L. Johnson, S. A. Kim, National Institute of Standards and Technology (United States); Z. N. Utegulov, Univ. of Nebraska, Lincoln (United States); B. T. Draine, Princeton Univ. (United States)

7032 IT Dependence of the multiphoton luminescence spectrum of single gold nanoparticles on the refractive index of the surrounding medium [7032-67]

M. Ruosch, D. Marti, P. Stoller, J. Rička, M. Frenz, Univ. of Bern (Switzerland) 
7032 1X Light-induced growth of monodisperse silver nanoparticles with tunable SPR properties and wavelength self-limiting effect (Invited Paper) [7032-71]

$X$. Zheng, Jilin Univ. (China) and The City College of New York (United States);

J. R. Lombardi, The City College of New York (United States)

$70321 Y \quad$ Multipolar tensor analysis of second-harmonic radiation from gold nanoparticles [7032-72]

S. Kujala, B. K. Canfield, M. Kauranen, Tampere Univ. of Technology (Finland); Y. Svirko,

J. Turunen, Univ. of Joensuu (Finland)

$70321 Z$ Optical trapping of nanoshells near resonance [7032-73]

B. C. Hester, R. B. Kishore, K. Helmerson, National Institute of Standards and Technology

(United States); N. J. Halas, C. Levin, Rice Univ. (United States)

PHENOMENA IN NANOPLASMONICS I

703221 Plasmon scanner and multiplexer (Invited Paper) [7032-75]

V. Vlasko-Vlasov, A. Imre, J. Pearson, J. Hiller, U. Welp, Argonne National Lab. (United States)

703222 Design considerations of selective polariton generators for multi-state plasmonic devices [7032-76]

N. Sedoglavich, R. Künnemeyer, The Univ. of Waikato (New Zealand); J. C. Sharpe, HortResearch (New Zealand)

703223 Fabrication and magneto-optical responses of AU-Bi:YIG films [7032-77]

R. Fujikawa, A. V. Baryshev, A. B. Khanikaev, J. Kim, H. Uchida, M. Inove, Toyohashi Univ. of Technology (Japan)

703224 Emissive efficiency enhancement of $\mathrm{Alq}_{3}$ and prospects for plasmon-enhanced organic electroluminescence [7032-78]

W. Li, Univ. of Rochester (United States); S. Pan, Univ. of Alabama (United States);

L. J. Rothberg, Univ. of Rochester (United States)

\section{PHENOMENA IN NANOPLASMONICS II}

703225 Femtosecond shape transformation dynamics of silver nanoparticles in glass [7032-80]

A. A. Unal, A. Stalmashonak, G. Seifert, H. Graener, Martin-Luther Univ. (Germany)

7032 2A Demonstration of multilayer titanium photonic crystals with 100-nm feature sizes [7032-85] S.-C. Wu, C.-D. Lin, National Nano Device Labs. (Taiwan); Y.-L. Yang, National Chiao Tung Univ. (Taiwan); J.-S. Chen, National Nano Device Labs. (Taiwan); Y.-T. Huang, National Chiao Tung Univ. (Taiwan)

\section{POSTER SESSION}

7032 2C Scattering of electromagnetic waves by small magnetic ellipsoidal particles [7032-87]

S. Puri, G. Mukhopadhyay, Indian Institute of Technology, Bombay (India) 
7032 2D Study of surface plasmon statistics by optical methods [7032-88]

D. Oszetzky, N. Kroó, A. Nagy, A. Czitrovszky, Research Institute for Solid State Physics and Optics (Hungary)

7032 2G A sensitivity study of the localised surface plasmon resonance of high-definition structured silver nanoparticles in solution [7032-91]

D. Charles, Trinity College Dublin (Ireland); P. Fournet, S. Cunningham, National Univ. of Ireland, Galway (Ireland); D. Ledwith, J. M. Kelly, W. Blau, Trinity College Dublin (Ireland); M. B. Fournet, National Univ. of Ireland, Galway (Ireland)

Author Index 
Downloaded From: https://www.spiedigitallibrary.org/conference-proceedings-of-spie on 26 Apr 2023

Terms of Use: https://www.spiedigitallibrary.org/terms-of-use 


\title{
Conference Committee
}

\author{
Symposium Chairs
}

David L. Andrews, University of East Anglia Norwich (United Kingdom) James G. Grote, Air Force Research Laboratory (United States)

Kevin J. Liddane, Oerlikon Optics USA, Inc. (United States)

Conference Chair

Mark I. Stockman, Georgia State University (United States)

Program Committee

Martin Aeschlimann, Universität Kaiserslautern (Germany)

David J. Bergman, Tel Aviv University (Israel)

Jochen Feldmann, Ludwig-Maximilians-Universität München

(Germany)

Harald W. Giessen, Universität Stuttgart (Germany)

Naomi J. Halas, Rice University (United States)

Martti Kauranen, Tampere University of Technology (Finland)

Satoshi Kawata, Osaka University (Japan)

Fritz Keilmann, Max-Planck-Institut für Biochemie (Germany)

Victor I. Klimov, Los Alamos National Laboratory (United States)

Aaron Lewis, The Hebrew University of Jerusalem (Israel)

Olivier J. F. Martin, École Polytechnique Fédérale de Lausanne

(Switzerland)

Martin Moskovits, University of California, Santa Barbara (United States)

Peter J. Nordlander, Rice University (United States)

Lukas Novotny, University of Rochester (United States)

Motoichi Ohtsu, The University of Tokyo (Japan)

John B. Pendry, Imperial College London (United Kingdom)

Lewis J. Rothberg, University of Rochester (United States)

Vahid Sandoghdar, ETH Zürich (Switzerland)

George C. Schatz, Northwestern University (United States)

Tigran V. Shahbazyan, Jackson State University (United States)

Vladimir M. Shalaev, Purdue University (United States)

Gennady Shvets, The University of Texas at Austin (United States)

Din Ping Tsai, National Taiwan University (Taiwan)

Nikolay I. Zheludev, University of Southampton (United Kingdom)

Joseph Zyss, Ecole Normale Supérieure de Cachan (France) 
Session Chairs

1 Special Session: Novel Trends in Nanoplasmonics I

Mark I. Stockman, Georgia State University (United States)

2 Plasmonic Nanoantennas I

Harry A. Atwater, Jr., California Institute of Technology (United States)

3 Plasmonic Nanoantennas II

A. Femius Koenderink, FOM Institute for Atomic and Molecular Physics (Netherlands)

$4 \quad$ Ultrafast Nanoplasmonics

Nikolay I. Zheludev, University of Southampton (United Kingdom)

Harald W. Giessen, Universität Stuttgart (Germany)

5 Quantum Nanoplasmonics and Related Phenomena I

Naomi J. Halas, Rice University (United States)

6 Quantum Nanoplasmonics and Related Phenomena II

Fransisco Javier García de Abajo, Consejo Superior de Investigaciones Científicas (Spain)

$7 \quad$ Nanoplasmonic Sensing, Including SERS

Niek F. van Hulst, Institut de Ciències Fotòniques (Spain)

8 Optical Functionalities in Plasmonics and Related Subjects

Enzo M. di Fabrizio, Università degli studi Magna Graecia di Catanzaro (Italy)

9 Transfer and Concentration of Optical Energy on Nanoscale I

Nader Engheta, University of Pennsylvania (United States)

10 Transfer and Concentration of Optical Energy on Nanoscale II

Anatoly V. Zayats, Queen's University Belfast (United Kingdom)

11 Plasmonic Properties of Complex Nanostructures

Meir Orenstein, Technion-Israel Institute of Technology (Israel)

12 NanoMeta

Vladimir M. Shalaev, Purdue University (United States)

13 Special Session: Nonlinear and Ultrafast Nanoplasmonics

Peter J. Nordlander, Rice University (United States)

14 Special Session: Novel Trends in Nanoplasmonics II

Harald W. Giessen, Universität Stuttgart (Germany) 
15 Plasmonic Sensing and Enhancement

Dai-sik Kim, Seoul National University (South Korea)

16 Laser-Induced Processes and Nonlinear Nanoplasmonics

Martti Kauranen, Tampere University of Technology (Finland)

17 Phenomena in Nanoplasmonics I

John R. Lombardi, City College, CUNY (United States)

18 Phenomena in Nanoplasmonics II

Masayuki Naya, FUJIFILM Corporation (Japan) 